\title{
Glacier Retreat Results in Loss of Fungal Diversity
}

\author{
Masaharu Tsuji ${ }^{1,{ }^{*},}$, Warwick F. Vincent ${ }^{2, *}$, Yukiko Tanabe ${ }^{3,4}$ and Masaki Uchida ${ }^{3,4}$ \\ 1 National Institute of Technology, Asahikawa College, Department of Materials Chemistry, Asahikawa 071- \\ 8142, Japan \\ 2 Université Laval, Département de Biologie, Takuvik \& Centre for Northern Studies (CEN), Québec, QC G1V \\ 0A6, Canada \\ 3 National Institute of Polar Research (NIPR), Biology group, Tachikawa, 190-8158, Japan \\ 4 SOKENDAI (The Graduate University for Advanced Studies), Department of Polar Science, Tachikawa, \\ 190-8158, Japan \\ * Correspondence: spindletuber@gmail.com; warwick.vincent@bio.ulaval.ca
}

\begin{abstract}
Walker Glacier near the northern coast of Ellesmere Island in the High Canadian Arctic (terrestrial margin of the 'Last Ice Area') is undergoing rapid ice attrition in response to climate change. We applied culture and molecular methods to investigate fungal diversity in sediments at the terminus of this glacier. Analysis of the mycoflora composition showed that the Walker Glacier isolates separated into two clusters: the surface of the glacier ice and the glacier foreland. The recently exposed soils of the foreland had a lower fungal diversity and different species from those on the ice, with the exception of five species that occurred in both habitats. This loss of glacial ice in the Arctic is therefore resulting in the loss of habitats for cold-dwelling fungal species. Fungal diversity is a potentially rich biological resource of glacial ecosystems, with unique taxa. The rapid loss of these glacial habitats underscores the urgency for more detailed surveys of fungal diversity in the High Arctic, and the need for further isolation of strains as well as cryopreservation of environmental microbiome samples for future research and conservation.
\end{abstract}

Keywords: glacial retreat; Walker Glacier; endangered fungi; climate change; mycoflora

\section{Introduction}

Glaciers currently occupy approximately $10 \%$ of the Earth's surface [1], but are now retreating and shrinking throughout the world [2] as a consequence of global climate change [3-4]. For example, glaciers in the Alps have lost about 50\% of their surface area during the past 150 years [5]. Austre Brøggerbreen $\left(79^{\circ} \mathrm{N}, 12^{\circ} \mathrm{E}\right)$, located near $\mathrm{Ny}$-Ålesund in the Svalbard archipelago, Norway, lost approximately $1.86 \mathrm{~km}^{2}$ of ice between 1936 and 2010 [6], and the glacier has retreated by $480 \mathrm{~m}$ in the last 20 years [7]. Glaciers provide habitats for microbial communities in the cryosphere, and supply water to streams, rivers, wetlands, and coastal oceans [8]. Glacial ice communities may differ from those found in glacier foreland habitats [9]. As glaciers retreat, rocks and sediments with less available nutrients are released and uncovered from the ice $[6,10]$. These substrates provide a habitat for bacteria and fungi that can grow under cold oligotrophic soil conditions [11-12]. Fungi act as decomposers and play key biogeochemical roles such as nutrient cycling in ecosystems [13], and losses in their diversity are therefore of broader concern for the functioning of the biosphere.

Walker Glacier (unofficial name; $83^{\circ} 00^{\prime} \mathrm{N}, 72^{\circ} 12^{\prime} \mathrm{W}$ ) is located on the far northern coast of Ellesmere Island in the Canadian High Arctic (Fig. 1). This region is at the northern limit of Quttinirpaaq National Park, Nunavut, where climate-related effects on the cryosphere have been observed over the past two decades [14-16]. This coastal zone is also the terrestrial margin of the 'Last Ice Area' (LIA), which contains the thickest ice in the Arctic Ocean and is viewed as the ultimate refuge for certain polar species [17]. However, concerns have been expressed about the rapid warming and ice attrition taking place in 
the LIA, and the loss of ice-dependent habitats at its coastal margin [18]. At the Walker Glacier site, GPS measurements were taken on July 20, 2013 from a datum pole placed at this location by Paul T. Walker on July 10, 1959 (Fig. 1, $83^{\circ} 00^{\prime} \mathrm{N}, 72^{\circ} 12^{\prime} \mathrm{W}$ ) showed that the glacier had retreated by $71 \mathrm{~m}$ over the preceding 54 years at an average rate of 1.3 $\mathrm{m} /$ year. Repeated GPS measurements at this location during the current survey (July 21, 2016) showed that it had retreated an additional $10 \mathrm{~m}$, at an average rate of $3.3 \mathrm{~m} / \mathrm{year}$ [19]. These observations suggested that Walker Glacier is in a retreating phase and that the rate of retreat is accelerating.

In our previous study, four new basidiomycete yeasts were described from this coastal LIA region, and two of the four new species were found at the Walker Glacier site [19-22]. To understand further the fungal taxa inhabiting glacier termini that are likely to be affected by global warming, we extended this work to the full communities by fungal culturing methods, to evaluate the diversity of mycoflora on Walker Glacier and its glacier foreland.

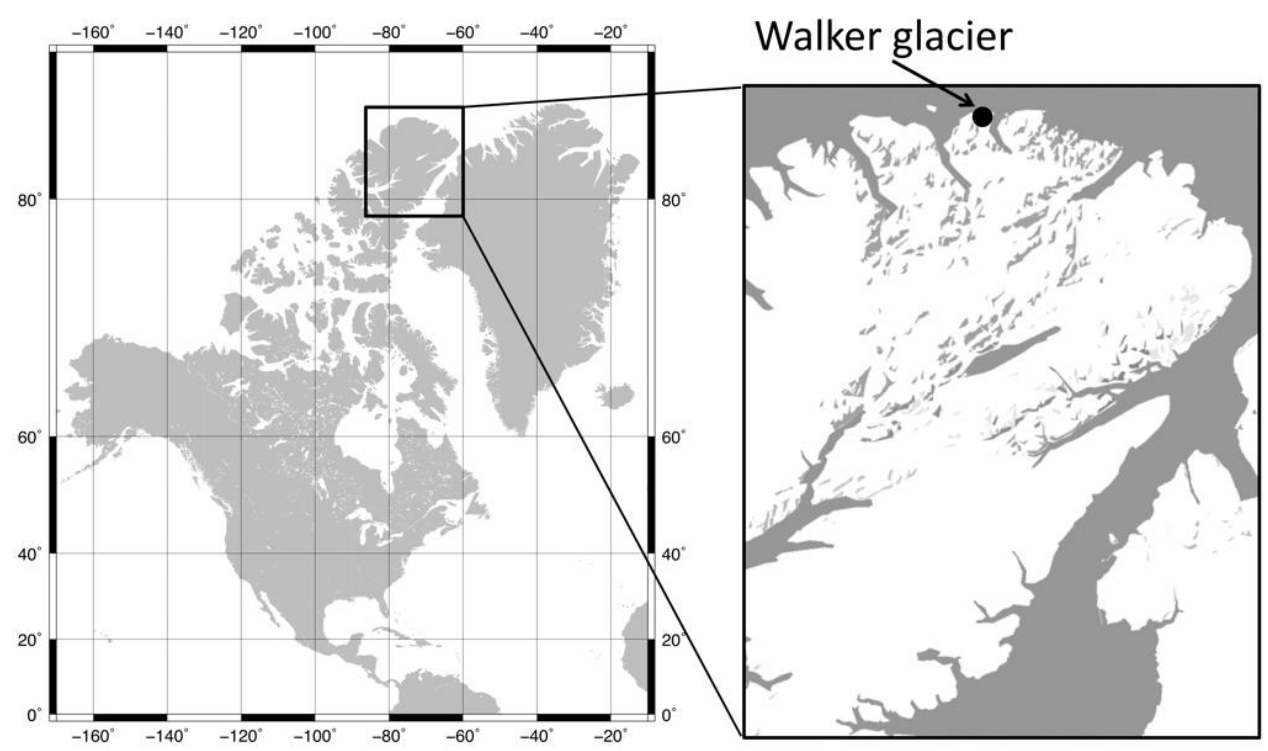

Figure 1. Location map of Ellesmere Island and Walker Glacier in the Canadian High Arctic.

\section{Materials and Methods}

\subsection{Fungal isolation}

Sediment samples were scraped from the surface of the melting ice face and terminal deposits of Walker Glacier (unofficial name; $83^{\circ} 00^{\prime} \mathrm{N}, 72^{\circ} 12^{\prime} \mathrm{W}$ ), northern Ellesmere Island, Nunavut, Canada, on July 16, 2016, and transferred to sterile 5-mL tubes; other sites and sampling details are given in Tsuji et al. [19]. Two sites were located on the glacial ice: Site 0 at $0.3 \mathrm{~m}$ from the base of the glacier and Site 1 at the base of the glacier. An additional seven sites were located on the exposed ground below the glacier. Sites 2 and 3 were $25 \mathrm{~m}$ and $40 \mathrm{~m}$ from the glacier terminus, respectively. Site 4 was located $55 \mathrm{~m}$ from the terminus of the glacier in an area that had been uncovered by the glacier retreat over the last 50 years. Site 5 was located approximately $71 \mathrm{~m}$ from the glacier, which was the position of the glacier terminus in 1959. Sites 6, 7 and 8 were located at 85, 100 and $132 \mathrm{~m}$, respectively, from the glacier terminus (Table 1 ). Within one hour after sampling, the samples were transferred to a $-20^{\circ} \mathrm{C}$ freezer and stored at this temperature until analysis.

Fungal isolates were cultured from the nine samples. The sediment subsamples $(0.1$ g) were directly plated onto potato dextrose agar (PDA) (Difco, Becton Dickinson Japan, Tokyo, Japan) containing $50 \mu \mathrm{g} / \mathrm{mL}$ chloramphenicol and incubated at $10{ }^{\circ} \mathrm{C}$ for up to 3 
weeks. Fungal colonies of different morphologies were streaked onto new PDA plates until individual colonies were isolated.

Table 1. Sampling site coordinates and distance for the glacier terminus of Walker Glacier.

\begin{tabular}{ccccc}
\hline & Latitude & Longitude & $\begin{array}{c}\text { Distance from the glacier } \\
\text { terminus }(\mathbf{m})\end{array}$ & $\begin{array}{c}\text { Additional comment to } \\
\text { sampling site }\end{array}$ \\
\hline Site 0 & $83^{\circ} 00.659^{\prime} \mathrm{N}$ & $72^{\circ} 12.721^{\prime} \mathrm{W}$ & $-0.3^{\mathrm{a}}$ & On the glacier \\
Site 1 & $83^{\circ} 00.659^{\prime} \mathrm{N}$ & $72^{\circ} 12.697^{\prime} \mathrm{W}$ & 0 & On the glacier \\
Site 2 & $83^{\circ} 00.647^{\prime} \mathrm{N}$ & $72^{\circ} 12.621^{\prime} \mathrm{W}$ & 25 & 40 \\
Site 3 & $83^{\circ} 00.639^{\prime} \mathrm{N}$ & $72^{\circ} 12.644^{\prime} \mathrm{W}$ & 55 & 71 \\
Site 4 & $83^{\circ} 00.638^{\prime} \mathrm{N}$ & $72^{\circ} 12.555^{\prime} \mathrm{W}$ & 85 & Glacier terminus in 1959 \\
Site 5 & $83^{\circ} 00.632^{\prime} \mathrm{N}$ & $72^{\circ} 12.504^{\prime} \mathrm{W}$ & 100 & 132 \\
Site 6 & $83^{\circ} 00.623^{\prime} \mathrm{N}$ & $72^{\circ} 12.512^{\prime} \mathrm{W}$ & $72^{\circ} 12.467^{\prime} \mathrm{W}$ & \\
Site 7 & $83^{\circ} 00.615^{\prime} \mathrm{N}$ & $72^{\circ} 12.367^{\prime} \mathrm{W}$ & \\
Site 8 & $83^{\circ} 00.602^{\prime} \mathrm{N}$ & &
\end{tabular}

a Site 0 was located upstream of the glacier terminus.

\subsection{DNA sequencing, species identification, and data analysis}

A disk of $3 \mathrm{~mm}$ in diam were taken from each fungal colony and placed into $1.5 \mathrm{~mL}$ tubes with $100 \mu \mathrm{L}$ of sterile distilled water. DNA was extracted from fungal colonies using a NucleoSpin Microbial DNA kit (Takara Bio Inc., Siga, Japan) following the manufacturer's protocol. The extracted DNA was then amplified by polymerase chain reaction (PCR) using KOD-plus DNA polymerase (Toyobo, Osaka, Japan) with the following primers: ITS1F (5'-GTAACAAGGTTTCCGT) [23] and NL4 (5'- GGTCCGTGTTTCAAGACGG). These primers are for two DNA sequences that are widely used in molecular fungal taxonomy: the ITS region and the D1/D2 domain of the LSU rDNA gene. The PCR conditions were as follows: primary template melting, $5 \mathrm{~min}$ at $94^{\circ} \mathrm{C}$; 35 cycles of $10 \mathrm{~s}$ at $98^{\circ} \mathrm{C}$ (melting), $30 \mathrm{~s}$ at $50-65^{\circ} \mathrm{C}$ (primer annealing) and $90 \mathrm{~s}$ at $68^{\circ} \mathrm{C}$ (elongation); and $10 \mathrm{~min}$ at $68^{\circ} \mathrm{C}$ (final elongation). PCR was carried out using an Eppendorf Master Cycler Nexus (Eppendorf Japan, Tokyo, Japan). The amplified DNA fragments were purified using Sephacryl S-400HR (Sigma-Aldrich, Tokyo, Japan). The DNA sequences were determined using an ABI Prism 3130xl sequencer (Applied Biosystems, Life Technologies, Tokyo, Japan), and the sequences were deposited in GenBank. The GenBank accession numbers of all the sequences analyzed in this study are listed in supplemental Table S1. The fungal species identifications were by BLAST analysis based on sequence homology.

In order to estimate fungal community similarity among the sampling sites based on ITS region and D1/D2 domain of the LSU rDNA gene, a hierarchical cluster analysis of fungal communities was carried out using Bray-Curtis similarity and a dendrogram inferred with the average linkage method [19]. These analyses were performed in $\mathrm{R}$ using the vegan package.

\section{Results and Discussion}

In total, 325 fungal strains were isolated from the nine glacial sediment samples collected from Walker Glacier (Table 1), and of these 273 were successfully extracted and DNA sequenced. There were 23-37 fungal strains obtained from each sampling site. Based on the ITS region sequences and D1/D2 domain sequences of the LSU rDNA gene, the fungal strains were classified into ten species of ascomycetes, 12 species of basidiomycetes, and six species of zygomycetes, including unclassified species. The number of fungal strains isolated from each site is shown in supplemental Table S1. The abundance and occurrence of the isolated fungal species among the nine sampling sites were statistically compared by hierarchical clustering. The mycoflora composition showed clustering between several pairs of adjacent sites ( 0 and $1 ; 7$ and $8 ; 5$ and 6$)$, but there was an overall 
separation into two clusters: isolates from the glacier ice (Site 0 and Site 1), and isolates from sites 2 to 8 in the glacier foreland (Fig. 2).

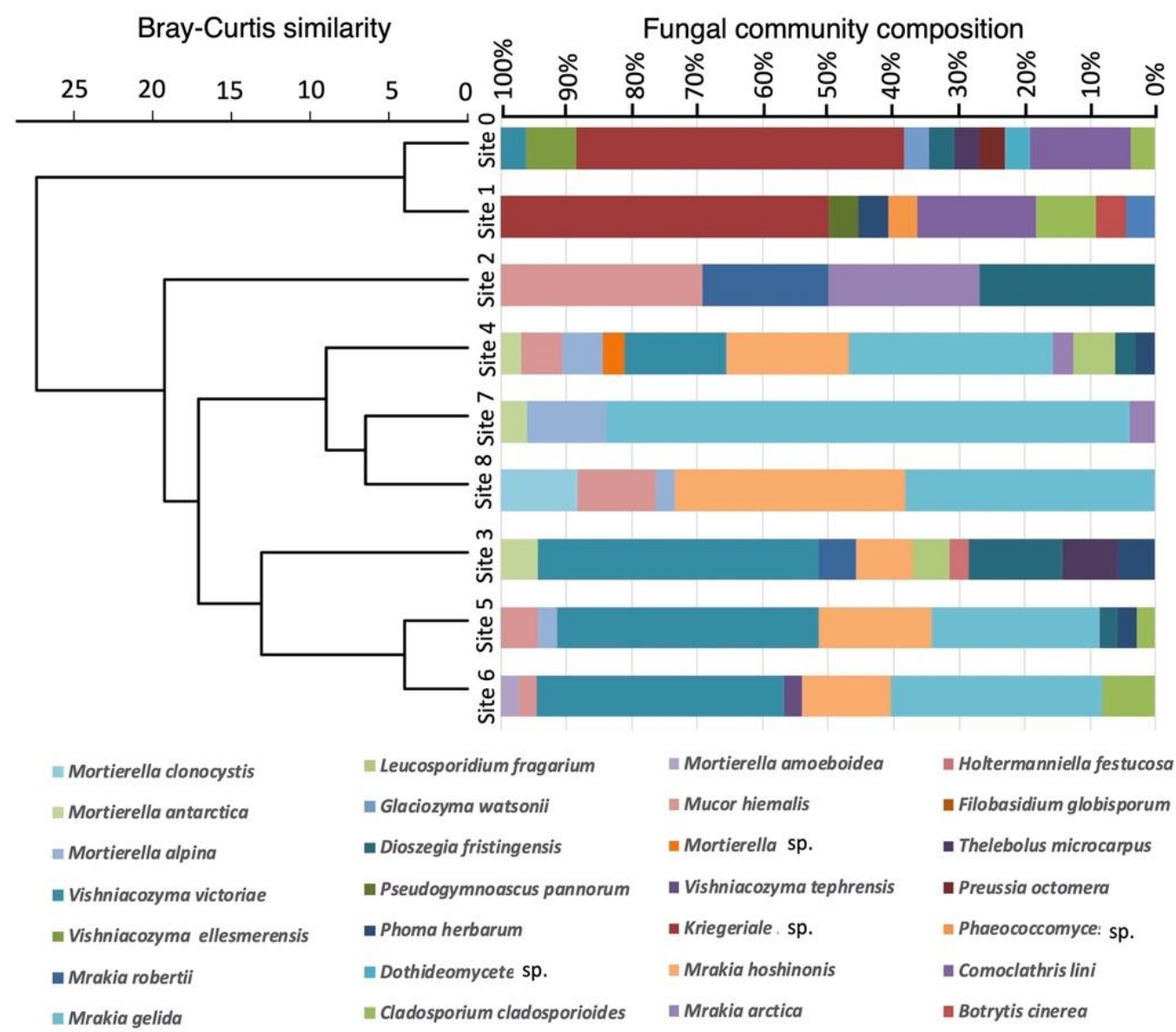

Figure 2. Dendrogram based on Bray-Curtis dissimilarities between nine sites on Walker Glacier and its foreland.

The fungal community composition of each site was clustered on the Bray-Curtis similarity measure.

The origin of each isolate was subsequently examined according to the two location clusters. In total, we isolated 15 fungal species from the glacier and 18 from the glacier foreland. Only five of the 15 fungal species isolated from the glacier samples (Cladosporium cladosporioides, Dioszegia fristingensis, Phoma herbarum, Thelebolus microcarpus, and Vishniacozyma victoriae) were also isolated from the glacier foreland samples (Fig.3, supplemental Table S2). 


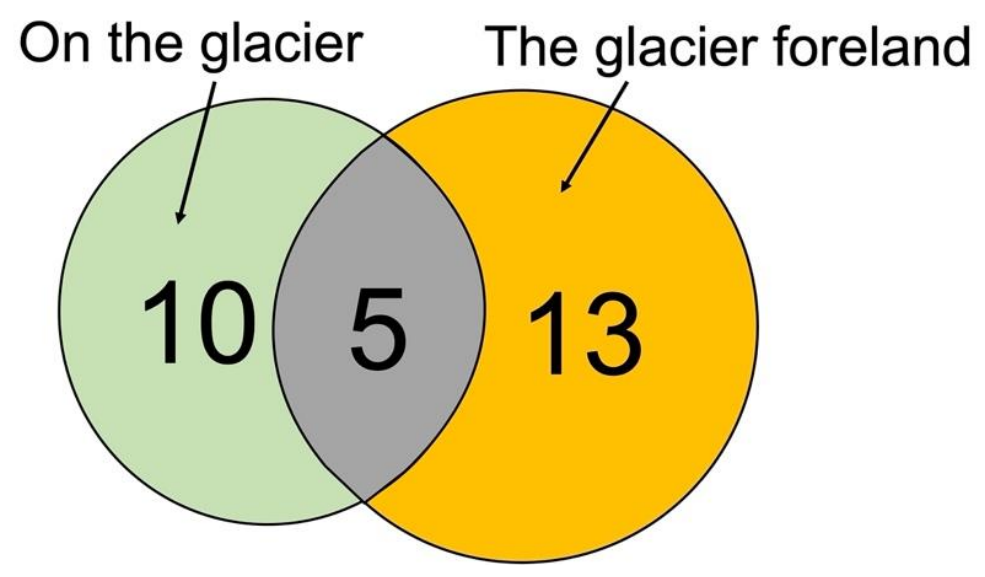

Figure 3. Venn diagram showing overlapping and non-overlapping fungal species isolated from Walker Glacier and its foreland.

We have previously isolated two basidiomycetous yeasts, $M$. hoshinonis, and V. ellesmerensis, from Walker Glacier and have described them as new fungal species [19, 22]. Mrakia hoshinonis has also been isolated from the Calderone Glacier in Italy and Iceland [24], however no sequences with high homology $(>95 \%)$ in the ITS region with $V$. ellesmerensis has been registered to date in GenBank. These results suggested that M. hoshinonis may be widely distributed in the Arctic and alpine regions while $V$. ellesmerensis is more locally restricted and perhaps endemic to the LIA region.

The UNITE database (https://unite.ut.ee/) determines the homology between the ITS region sequence of a fungus and its sequence in the database and indicates where the fungus was reported from [25]. The current study indicated five potentially new fungal species from Walker Glacier and its glacier foreland. They were classified as Dothideomycetes sp., Ascomycota sp., Herpotrichiellaceae sp., Kriegerialess sp. and Mortierella sp. according to the sequence homology of ITS region and D1/D2 region of 26S RNA (Table S1). Using the UNITE database, we identified where fungi with high homology to the ITS region sequences of the five potential new fungal species in this study have been reported from. One strain of Dothideomycetes sp. G2-4-2 was isolated from Walker Glacier, and this strain had $100 \%$ similarity to the ITS region sequence with three strains of Dothideomycetes sp. (accession number: MF043960, MF043961, and MF043963). MF043960 and MF043963 were isolated from Qaanaaq Glacier, in a Greenland cryoconite region, and MF043961 was deposited in the DNA Data Bank as fungi isolated from Yala Glacier in a Himalayan cryoconite region. Strain G2-4-2 ITS region sequences also showed 100\% similarity with three strains of Preussia sp. (accession number: MK460382, MK460383, and KC333159) isolated from the Greenland Ice Sheet and cryoconite holes in a glacier in Svalbard, Norway [9, 26]. A strain of Ascomycota (GR1-1-20-1) isolated from Walker Glacier had 98\% ITS region sequence similarity to an uncultured fungal clone (accession number: FJ553913) isolated from soil from Skulow Lake in Canada and an uncultured fungal clone (accession number: FJ237066) from the snow-covered soil from the foreland of Rotmoosferner Glacier in Austria [27]. A strain of Herpotrichiellaceae (GR1-3-20-3) was found from Site 1 at Walker glacier, and this strain showed $99 \%$ sequence homology to an uncultured fungal clone (accession number: KC965554) has been reported from Prince Patrick Island, Canada. Our Walker Glacier isolates also included 24 strains of Kriegeriales species, which appear to be a major component of the fungal cryo-community. These Kriegeriales strains had $88 \%$ ITS region sequence homology with a basidiomycete strain from an ice core obtained in the Altai Mountains, western Siberia (accession number: AB474394). From glacier foreland, Mortierella sp. (GR4-1-20-5) had 99\% ITS region sequence similarity with another uncultured fungus clone (accession number: KC965293) from Banks Island in Canada [28].

The five new fungal species from on Walker Glacier and the glacier foreland, and our strains showing high homology with Kriegeriales species were registered in the DNA 
databank of ITS region sequences. It may be that the Kriegeriales strain is also endemic to the LIA, as suggested for $V$. ellesmerensis. Most of the potentially new fungal species isolated from Walker Glacier (sites 0 and 1) were not present among the isolates from the glacier foreland (sites 2 to 8 ).

The results of this study suggest a unique ice-dependent mycoflora on Walker Glacier, with strains that were not able to compete or survive in the glacier foreland environment. Fungi living on glaciers likely play key biogeochemical roles on these cryo-ecosystems in carbon and nutrient cycling [13] and may have unique biochemical and physiological characteristics. The ongoing retreat of High Arctic glaciers due to global warming, which is amplified at these high northern latitudes $[29,30]$, is resulting in accelerated habitat loss and may lead to the eventual extinction of these extreme cold-adapted microbes. Elsewhere along the LIA margin of Canada and Greenland, the highest latitude coastal region of the Arctic, there is recent evidence of complete loss of specific ecosystem types, and widespread ice attrition [18]. The fungal taxa described here are prone to ongoing climate warming and habitat loss, which underscores the urgency of greenhouse gas mitigation at a global scale as well as the importance of local conservation initiatives and biodiversity surveys. Part of that conservation effort should include cryo-preservation of environmental microbiome samples from High Arctic glaciers, as well as further isolation of fungal strains from these habitats for culture and analysis.

Supplementary Materials: The following are available online at www.mdpi.com/xxx/s1, Table S1: Species names, strain names, sources of isolates, and GenBank accession number of the ITS region and D1/Dr2 domain sequences of isolated fungi, Table S2: Number of strains isolated from each sampling site.

Author Contributions: Conceived and designed the experiments: MT, YT, WFV and MU. Performed the field sampling: YT and WFV. Performed the laboratory experiments and analyses: MT. Analysed the data: MT. Wrote the manuscript: MT with input from all authors.

Funding: This work was supported by the NIPR Research Project (KP-309), a JSPS Grant-in-Aid for Young Scientists (A) to M. Tsuji (no. 16H06211), Institution for Fermentation, Osaka, for Young Scientists to M. Tsuji (no. Y-2018-004), and the ArCS (Arctic Challenge for Sustainability) II project (Program Grant Number JPMXD1420318865) provided by the Ministry of Education, Culture, Sports, Science and Technology, Japan. Additional support for the fieldwork was provided through the project NEIGE (Northern Ellesmere Island in the Global Environment) funded through the Natural Sciences and Engineering Research Council of Canada (NSERC), the NCE program ArcticNet, and the CFREF program Sentinel North.

Acknowledgments: We thank Prof. M. Kumagai, Ritsumeikan University, Prof. A. I. Culley, Université Laval, and Mr. D. Sarrazin, CEN, for assistance in the field. We are grateful to Parks Canada and CEN for the use of their facilities at Ward Hunt Island in Quttinirpaaq National Park, Nunavut, and the Polar Continental Shelf Program (PCSP) for aircraft support. The authors also thank K. Watanabe and M. Mori for providing technical assistance. This work is also a contribution to the International Arctic Science Committee (IASC) project T-MOSAiC (Terrestrial Multidisciplinary distributed Observatories for the Study of Arctic Connections).

Conflicts of Interest: The authors declare no competing interests. 


\section{References}

1. Cauvy-Fraunié, S., Dangles, O. A global synthesis of biodiversity responses to glacier retreat. Nat. Ecol. Evol. 2019, 3, 16751685.

2. Zemp, M., Huss, M., Thibert, E, EcKert, N., McNabb, R., Huber, J., Barandun, M., Machguth, H., Nussbaumer, S.U., GärtnerRoser, I., et al. Global glacier mass changes and their contributions to sea-level rise from 1961 to 2016. Nature 2019, 568, 382386.

3. Qin, D., Ding, Y. Key issues on cryospheric changes, trends and their impacts. Adv. Clim. Change Res. 2010, 1, 1-10.

4. IPCC Special Report on the Ocean and Cryosphere in a Changing Climate. https://www.ipcc.ch/srocc/, (accessed on $8^{\text {th }}$ December 2021).

5. Zemp, M., Haeberli, W., Hoelzle, M. \& Paul, F. Alpine glaciers to disappear within decades? Geophys. Res. Lett. 2006, 33, L13504.

6. Nowak, A. Hodson, A. Changes in meltwater chemistry over a 20-year period following a thermal regime switch from polythermal to cold-based glaciation at Austre Brøggerbreen, Svalbard. Polar Res. 2014, 33, 22779.

7. Kume, A., Nakatsubo, T., Bekku, Y., Masuzawa, T. Ecological significance of different growth forms of purple Saxifrage, Saxifraga oppositifolia L., in the High Arctic , Ny-Ålesund, Svalbard. Arct. Antarct. Alp. Res. 1999, 31, 27-33.

8. Sharp, M., Parkes, J., Cragg, B., Fairchild, I.J., Lamb, H., Tranter, M. Widespread bacterial populations at glacier beds and their relationship to rock weathering and carbon cycling. Geology, 1999, 27, 107-110.

9. Edwards, A., Douglas, B., Anesio, A.M., Rassner, S.M., Irvine-Fynn T. D. L., Sattler, B., Griffith G.W. A distinctive fungal community inhabiting cryoconite holes on glaciers in Svalbard. Fungal Ecol. 2013, 6, 168-176.

10. Bardgett, R.D., Richter, A,. Bol, R., Garnett, M.H., Bäumler, R., Xu, X., Lopez-Capel, E., Manning, D.A.C., Hobbs, P.J., Hartley, I.R., et al. Heterotrophic microbial communities use ancient carbon following glacial retreat. Biol. Lett. 2007, 3, 487490.

11. Bergero, R., Girlanda, M., Varese, G.C., Intili, D., Luppi, A.M. Psychrooligotrophic fungi from arctic soils of Franz Joseph Land. Polar Biol. 1999, 21, 361-368.

12. Sattin, S.R. Cleveland, C.C., Hood, E., Reed S.C., King, A, J., Schmidt, S. K., Robeson, M. S., Ascarrunz, N., Neergut, D.R. Functional shifts in unvegetated, perhumid, recently-deglaciated soils do not correlate with shifts in soil bacterial community composition. J. Microbiol. 2009, 47, 673-681.

13. Welander, U. Microbial degradation of organic pollutants in soil in a cold climate. Soil Sediment Contam. 2005, 14, 281-291.

14. Copland, L., Mueller, D., eds., Arctic Ice Shelves and Ice Islands, 2017, Springer.

15. Vincent, W.F., Fortier, D., Lévsque, E., Boulanger-Lapointe, N., Tremblay, B., Sarrazin, D., Antoniades, D., Mueller, D.R. Extreme ecosystems and geosystems in the Canadian High Arctic: Ward Hunt Island and vicinity. Ecoscience, 2011, 18, 236261.

16. White, A., Copland, L. Area change of glaciers across Northern Ellesmere Island, Nunavut, between $\sim 1999$ and $\sim 2015$. J. Glaciol. 2018, 64, 609-623.

17. Newton, R., Pfirman, S., Tremblay, L.B., DeRepentigny, P. Defining the "ice shed" of the Arctic Ocean's Last Ice Area and its future evolution. Earth's Future, 2021, 9, e2021EF001988.

18. Vincent, W.F., Mueller, D. Witnessing ice habitat collapse in the Arctic. Science, 2020, 370, 1031-1032.

19. Tsuji, M., Tanabe, Y., Vincent, W.F., Uchida, M. Vishniacozyma ellesmerensis sp. nov., a new psychrophilic yeast isolated from a retreating glacier in the Canadian High Arctic. Int. J. Syst. Evol. Microbiol. 2019, 69, 696-700.

20. Tsuji, M., Tanabe, Y., Vincent, W.F., Uchida, M. Mrakia arctica sp. nov., a new psychrophilic yeast isolated from an ice island in the Canadian High Arctic. Mycoscience, 2018, 59, 54-58.

21. Tsuji, M., Tanabe, Y., Vincent, W.F., Uchida, M. Gelidatrema psychrophila sp. nov., a novel yeast species isolated from an ice island in the Canadian High Arctic. Mycoscience, 2018, 59, 67-70.

22. Tsuji, M., Tanabe, Y., Vincent, W.F., Uchida, M. Mrakia hoshinonis sp. nov., a novel psychrophilic yeast isolated from a retreating glacier on Ellesmere Island in the Canadian High Arctic. Int. J. Syst. Evol. Microbiol., 2019, 69, 944-948.

23. Gardes, M., Bruns, T. D. ITS primers with enhanced specificity for basidiomycetes-application to the identification of mycorrhizae and rusts. Mol. Ecol. 1993, 2, 113-118.

24. Turchetti, B., Sannino, C., Mezzasoma, A., Zucconi, L., Onofri, S., Buzzini, P. Mrakia stelviica sp. nov. and Mrakia montana sp. nov., two novel basidiomycetous yeast species isolated from cold environments. Int. J. Syst. Evol. Microbiol., 2020, 70, 704-4713.

25. Nilsson, R.H., Larsson, K.H., Taylor, A.F.S., Bengtsson-Palme, J., Jeppesen, T.S., Schigel, D., Kennedy, P., Picard, K., Glöckner, F.O., Tedersoo, L. et al. The UNITE database for molecular identification of fungi: handling dark taxa and parallel taxonomic classifications. Nucleic Acids Research, 2018, 47, D259-D264. 
26. Perini, L., Gostinčar, C., Anesio, A.M., Williamson, C., Tranter M., Gude-Cimerman, N. Darkening of the Greenland Ice Sheet: Fungal abundance and diversity are associated with algal bloom. Front. Microbiol. 2019, 10, 557.

27. Kuhnert, R., Oberkofler I., Peintner, U. Fungal growth and biomass development is boosted by plants in snow-covered soil. Microbiol. Ecol. 2012, 64, 79-90.

28. Timling, I., Walker, D.A., Nusbaum, C., Lennon, N.J., Taylor, D.L. Rich and cold: diversity, distribution and drivers of fungal communities in patterned-ground ecosystems of the North American Arctic. Mol. Ecol. 2014, 23, 3258-3272.

29. Vincent, W.F. Arctic climate change: Local impacts, global consequences, and policy implications. In: K. Coates, C. Holroyd (eds.). Palgrave Handbook of Arctic Policy and Politics. London, U.K., Palgrave Macmillan, 2020, pp. 507-526.

30. Bégin, P. N., Tanabe, Y., Kumagai, M., Culley, A. I., Paquette, M., Sarrazin, D., Uchida, M., Vincent, W.F. Extreme warming and regime shift toward amplified variability in a far northern lake. Limnol. Oceanogr. 2021, 66, S17-S29. 